\title{
DEVELOPMENT OF THERAPY APPROACH IN PATIENT WITH CHRONIC GRANULOCITY LEUKEMIA: CASE REPORT
}

Predrag Krstić ${ }^{1}$, Marija Elez ${ }^{1}$, Biljana Živanović-Todorić ${ }^{2}$, Gordana Ostojić ${ }^{3}$, Bela Balint ${ }^{4}$, Milomir Malešević $^{1}$ and Dragana Stamatović ${ }^{1}$ ${ }^{1}$ Hematology Clinic, Military Medical Academy, Belgrade, Serbia ${ }^{2}$ Institute of Pathology, Military Medical Academy, Belgrade, Serbia ${ }^{3}$ Clinic of Transfusiology, Military Medical Academy, Belgrade, Serbia ${ }^{4}$ Institute for Cardiovascular Diseases, Belgrade, Serbia

\section{RAZVOJ TERAPIJSKOG PRISTUPA KOD BOLESNIKA SA HRONIČNOM GRANULOCITNOM LEUKEMIJOM: PRIKAZ SLUČAJA}

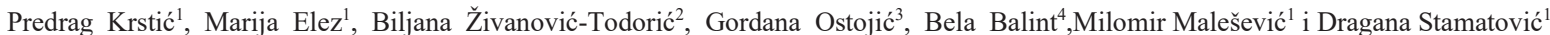

${ }^{\prime}$ Klinika za hematologiju, Vojnomedicinska akademija, Beograd, Srbija

${ }^{2}$ Institut za patologiju, Vojnomedicinska akademija, Beograd, Srbija

${ }^{3}$ Klinika za transfuziologiju, Vojnomedicinska akademija, Beograd, Srbija

${ }^{4}$ Institut za kardiovaskularne bolesti Dedinje, Beograd, Srbija

\begin{abstract}
Chronic granulocytic leukemia (CGL), $\mathrm{Ph}+$ is a chronic myeloproliferative disorder, which, due to its specificity for many decades, has attracted the attention of researchers of numerous specialties. This disease was among the first malignant haemopathies that received their "ID card" since molecular analyzes precisely defined the basic pathological substrate,that is, the origin of the disease. Over the past decades we have witnessed the evolution of the therapeutic approach in the treatment of CGL from oral cystostatic therapy, radiotherapy, through recombinant interferon alpha (IFN-alpha), haematopoeza stem cell transplantation, to the targeted molecular therapy of the tyrosine kinase inhibitor (TKI).

In this report we present patient with a diagnosis of CGL, $P h+i n$ the early chronic phase at the age of 13 years based on all relevant analyzes. During the past 26 years, all therapeutic modalities of CGL treatment were applied in patients, according to the time period, concluding with the second generation TKI, resulting in complete remission of diseases with excellent quality of life and identical expectations for the future, as well as in the healthy population.
\end{abstract}

Keywords: Chronic granulocytic leukemia, Ph + (CGL), Therapeutic approaches, case report.

\section{SAŽETAK}

Hronična granulocitna leukemija (CGL), Ph+ je hronično mijeloproliferativnooboljenje, koje zbog svoje specifičnosti više decenija unazad zaokuplja pažnju istraživača brojnih specijalnosti. Ovo oboljenje je medju prvim malignim hemopatijama dobilo svoju ,ličnu kartu“ obzirom da je molekularnim analizama precizno definisan osnovni patološki substrat, odnosno, ishodište bolesti. Tokom prethodnih decenija svedoci smo evidentnograzvoja terapijskog pristupa u lečenju CGL od peroralne cistostatske terapije, radioterapije, preko rekombinantnog interferona alfa (IFN-alfa), oblika transplantacije matičnih ćelija hematopoeze, do ciljane molekularne terapije oblika inhibitora tirozin kinaze (TKI)

Prikazujemo bolesnika kod koga je u dobi od 13 godina na osnovu svih relevantnih analiza dijagnostikovana $C G L, P h+u$ ranoj hroničnoj fazi. Tokom prethodnih 26 godina kod bolesnika su primenjeni svi terapijski modaliteti lečenja CGL, shodno vremenskom periodu, zaključno sa drugom generacijom TKI, što je rezultiralo kompletnom remisijom bolesti sa odličnim kvalitetom života $i$ istovetnim očekivanjima za budućnost, kao $i$ kod zdrave populacije.

Ključne reči: Hronična granulocitna leukemija, $P h+(C G L)$, Terapijski pristupi, prikaz slučaja. 


\section{INTRODUCTION}

Chronic granulocytic leukemia (CGL) is a highly specific disease that is defined by strict hematologic parameters that include a pathognomonic differential leukocyte count.Usually CGL is accompanied by the presence, in bone marrow cells, of the Ph chromosome, the first chromosomal anomaly to be regularly associated with a human neoplastic disease (1).CGL is predominantly a disease of the productive middle years of life, which maximizes its adverse impact on family life and family economics. The disease is of worldwide distribution and there is a slight male preponderance. The disease is characterized by an initial chronic phase when it behaves as a differentiated neoplasm and responds very well to simple, nonintensive therapy (1-3).

\section{CASE PRESENTATION}

We present male patients with whom he was diagnosed with CGL, $\mathrm{Ph}+$ in early chronic phase in 1992, when he was 13 years old. Clinical characteristics of the disease at the presentation were signs of anemia syndrome in the presence of organomegaly (hepatosplenomegaly). In haematological parameters, leukocytosis up to $275 \times 10^{9} / \mathrm{L}$ was detected with the presence of all forms of white lines in the peripheral blood smear, with anemia with hemoglobin of $89 \mathrm{~g} / \mathrm{L}$ and mild thrombocytosis up to $499 \times 10^{9} / \mathrm{L}$. Biopsy of thebone marrow confirmed the diagnosis of CGL with a chronic phase image, and cytogenetic analysis was confirmed by $\mathrm{Ph}$ chromosome. Introductory treatment was carried out with Hydroxiureom in a dose dependent on haematological parameters, which achieved cytoreduction, and in the next five months, the patient received recombinant IFN alpha at a dose of $9 \mathrm{U}$ per week. Clinical and hematologic remission of the disease with the maintenanceof the cytogenetic marker was achieved on the applied therapy. Bearing in mind the nature of the underlying disease, allogeneic haemopoietic stem cell transplant (MHH) transplantation from the family matched (in the HLA and $\mathrm{ABO}$ system) of the donor, born brother, was done in the future. The conditional regimen was conducted according to the myeloablative protocol in combination with oral formulation of Busulphan-Cyclophosphamide 2 with complete supportive therapy (adequate hydration, urotoprotection, prevention of mucositis and possible forms of infection). The source of the MSH was the bone marrow, with the patient on 27.12.1993 receiving a total of $1.56 \times 10^{8}$ cells with a nucleus (total nucelar cells -TNC) / kgTM in a suspension of 1170 $\mathrm{ml}$ of bone marrow. Prevention of graft versus host disease (GvHD) was carried out with dual immunosuppressive therapy (Cyclosporine A + Methotrexate according to the "short Seatle" protocol). The period of iatrogenic bone marrow aplasia was accompanied by oropharyngeal mucositis of grade 2 . The acceptance of the allogeneic coil, measured by the parameters of the blood count (neutrophil and platelet counts), was recorded from +18 . days after transplantation. Dana +40 . After transplantation complete donor chimerism has been proven. No signs of acute or chronic GvHD are registered. Remission of the disease to the cytogenetic level was maintained until August 1996. During this period, relapses of the disease were confirmed on cytogenetic and then haematological level, 32 months after the primary allogeneic transplantation of the MSH. Treatment of the first relapse begins with recombinant INF alpha at a dose of $9 \mathrm{MU}$ per week for three months. The therapy did not achieve the desired response at the cytogenetic level, so treatment was continued using immunoadaptive therapy, by infusion of lymphocytes taken from the same donor. The patient received three units of donor lymphocytes (DLI) on 10.12. and 30.12.1996. and February 17,1997 , in escalating doses $\left(2.6 \times 10^{7}, 4.1 \times 10^{7}\right.$, $\left.4.1 \times 10^{7} / \mathrm{kg} / \mathrm{bw}\right)$. Clinical monitoring did not record signs of acute GvHD. Hematological monitoring detects a gradual occurrence of pancytopenia, and in April 1997, bone marrow biopsy and myocardial infarction confirmed bone marrow aplasia as a potential adverse effect of DLI. Further treatment was carried out by the secondary allogeneic transplantation of the MSHfrom the identical family donor. In a conditioned regimen, according to bone marrow aplasia, the patient received only antitomocyte globulin (ATG - Fresenius) at a dose of $5 \mathrm{mg} / \mathrm{kg} / \mathrm{bw}$ for four days. The MSH source was the peripheral blood of the donor after a five-daypreparation of recombinant G-CSF at a dose of $5 \mathrm{mcg} / \mathrm{kg} / \mathrm{bw}$. Secondary transplantation was done on May 19, 1997. where the patient received $5.3 \times 10^{8} \mathrm{TNC} / \mathrm{kgTM}$, i.e., $15.5 \times 10^{6}$ $/ \mathrm{kg} / \mathrm{bw}$ CD34 + cells). Prevention of GvHD was not applied. Acceptance of the allogeneic coil is recorded via the number of neutrophils and platelets of +15 . days after transplantation,while cytogenetic and molecular analysis determine the complete remission of the disease with complete donor chiberism. Clinical monitoring did not show signs of acute or chronic GVHD. A complete remission of the disease was maintained until December 2002 (67months after secondary allogeneic MHH transplantation). During this period, late relapses of the disease were recorded at the cytogenetic level, and the treatment continued with the first generation tyrosine kinase inhibitor (Glivec) at a dose of $400 \mathrm{mg}$ per day. The desiredtherapeutic response (parsing of the disease at the cytogenetic level) was not achieved, and since October 2004 the preparation of the second generation TKI - Nilotinib was included in the therapy. This form of treatment achieves a complete remission of the disease down to the molecular level that has been maintained over the past 14 years.

\section{DISCUSSION}

Chronic granulocytic leukemia is a chronic myeloproliferative disease, a hematopoietic stem cell disease, characterized by a specific Phyladelphia chromosome, or reciprocal translocationbetween chromosomes 9 and 22 (1-3). Thanks to the significant advances in basic diagnostic procedures, CGL is one of the rare hematological diseases that has its own ID card from clinical symptoms and signs, through physical findings, haematological parameters, peripheral blood smear, bone marrow biopsy, cytogenetics to molecular markers (4). The incidence of CGL is $10-15$ people per 100000 inhabitants per year and occurs most frequently in the age between 60-65 years (5). 
The disease passes through three characteristic clinical phases, chronic, phase of acceleration and blast transformation phase, which are clearly defined on the basis of clinical, hematological and cytogenetic-molecular criteria $(5,6)$. Over the past decades, the therapeuticapproach to treating patients with CGL has been reduced and evolved along with a more precise clarification of the pathogenesis of the disease. The end of the 19th century was marked by the use of a arsenic preparation in the treatment of CGL or X radiation of enlarged spleen. The fifties of the 20th century began with the use of chemotherapy, initially Busulphanom, and then Hydroxiuree in patients with CGL. Hydroxiurea has been the most effective cytoreduction agent for this disease for decades, as was the case with our patients at the initial stage. Using various forms of cytoreductive therapy, clinical and hematologic remission of the disease in a negligible percentage of patients could be achieved, while the causative action on the disease itself was absent. In the early 1990s, patients with CGL were treated with recombinant IFN-alpha, a powerful immunomodulatory agent that opened a new era in the control of this malignant disease. Namely, for the first time, one agent acted at the cytogenetic level, bringing in the truth in a small group of patients, and a complete cytogenetic response. The next period was marked by the establishment of new cytogenetic response scales (from minimal to complete), which dictated the therapeutic approach (monotherapy with IFN alpha or combinations with other cytoreductive agents) (7). In the case of our patient, the proposed CGL treatment algorithm was followed in full according to the time period, and immunomodulatory therapy with IFN-alpha was also applied. Transplantation of stem cell hematopoiesis since 1979 (single transplantation) over the eighties and nineties of the 20th century was the standard in the treatment of patients with CGL, and this diagnosis was the most common indication for allogeneic transplantation froma related matched donor.

Based on clinical experience, the European Bone Marrow Transplantation Group(EBMT) has designed an EBMT prognostic score for predicting mortality rates in patients with CGL-treated allogeneic MSH transplantation based on a combination of a number of parameters related to patients and potential donors (7-9). In the case of our patient, since the initial treatment with cytoreductive and immunomodulatory therapy has achieved clinical and hematological control of the disease, without the desired response at the cytogenetic level, an indication is given that the treatment will continue with the allogeneic transplantation of the MSH from the family fully matching donor. In accordance with the current attitudes and the fact that it is a hematopoietic stem cell disease, the preparatory regime was myeloablative, thesource of the stem cells of the bone marrow, and the prevention of GvHD double immunosuppressive therapy $(8,9)$. In the post-transplant period, a timely engrafment was confirmed in our patient with the achievement of complete donor chimerism, and no clinicalor acute GvHD signs were recorded by clinical monitoring. Opinions regarding the monitoring of patients with CGL in whom allogeneic transplantation of the MSH occurred in the 1990s implied a three-month analysis of the cytogenetic finding, and then over the years and a molecular marker of the disease in order to timely diagnose the possible relapse of the underlying disease. In 1990, for the first time, infusion of donor lymphocytes (DLI) was used in the treatment of relapse of the disease after allogeneic transplantation $(7,10)$. Clinical observations have unambiguously confirmed that CGL disease is in the first place by degree of sensitivity to applied DLI, that is, that this therapeutic procedure can achieve a significant degree of secondary remission of the disease (11). The most common side effects of DLI include GvHD and bone marrow aplasia $(12,13)$. In our patient, three years after allogeneic transplantation, a rough relapse of the disease was diagnosed, and treatment was performed with three escalating doses of DLI from the original family donor, according to current recommendations for treatment in these situations. Newborn bone marrow aplasia with potentially fatal infectious complications can be interpreted as an adverse effect of DLIapplication. In this situation, the therapeutic approach for our patients was extremely limited. It is known that secondary allogeneic transplantation of the MSH in the case of leukemia relapse is an extremely complicated procedure, followed by a high degree of posttransplant morbidity and mortality, especially if one of the modalabative preparatory regimes $(13,14)$ is applied. In the late nineties of the last century, in order to overcome these complications, conditioned regimens of "reduced" intensity were designed primarily for secondary allogeneic transplantation of the MHH or elderly patients with associated illnesses $(2,13-15)$. In the phase of bone marrow aplasia after DLI our patient was only prepared with ATG, and the source of the MSH from the original family donor was peripheral blood in order to achieve the "graft-versus-leukemia" (GvL) effect needed to control the minimum residual illness. No additional immunosuppressive therapy has been applied to generate GvL effects. This treatment regimen again achieved a multi-year remission condition.

Further development of the therapeutic approach in the treatment of CGL patients afterthe MSH transplantation and the DLI application was based on the understanding of the molecular mechanism of the disease, and implied the use of tyrosine kinase inhibitors (TKI), starting in 1998 (15-17). The application of different generations of TKI led to the revolutionary control of CGL, concluding with the achievement of complete molecular remission of the disease $(4,10,14)$. Thanks to the introduction of TKI in CGL therapy and the achievement of molecular disease control, it can rightly be said that patients with CGL have identical life expectations as well as a healthy population. After the onset of the secondrelapse of the disease due to secondary allogeneic transplantation, our patient was initially included in the first, and then due to the incomplete response and the second generation TKI with long-term complete control of the disease and excellent quality of life. 


\section{CONCLUSION}

Current treatment of CGL over the past 130 years significantly evolved follow-up achievements in medicine and basic biological sciences. Due to a more precise view of the pathogenetic process in the onset and progression of CGL from the chronic phase to the form of acute leukemia, concurrently with molecular mechanisms, targeted drugs have been synthesized that stop the proliferation of malignant clones in this disease (TKI). The displayof our patients fully supports the development of a therapeutic approach in the treatment of CGL, cytoreductive therapy, immunomodulatory agents, MHC transplantation, application of cell therapy such as DLI to first and second generation TKI.

\section{DISCLOSURES}

No conflicts of interest, financial or otherwise, are declared by the authors.

\section{LITERATURE}

1. Spiers AS. Clinical manifestations of chronic granulocytic leukemia. Semin Oncol. 1995 Aug;22(4):380-95.

2. Saußele S, Silver RT. Management of chronic myeloid leukemia in blast crisis. Ann Hematol. 2015 Apr;94 Suppl 2:S159-65. doi: 10.1007/s00277-015-2324-0.

3. Zhou H, Xu R. Leukemia stem cells: the root of chronic myeloid leukemia. Protein Cell. 2015 Jun;6(6):403-12. doi: 10.1007/s13238-015-0143-7.

4. Goldman JM. Chronic myeloid leukemia: a historical perspective. Semin Hematol. 2010 Oct;47(4):302-11. doi: 10.1053/j.seminhematol.2010.07.001.

5. https://www.cancer.gov/publications/cancerterms/def/ chronic-granulocytic-leukemia

6. Eden RE, Coviello JM. Cancer, Leukemia, Myelogenous, Chronic (CML, Chronic Granulocytic Leukemia). 2018 Oct 27. StatPearls [Internet]. Treasure Island (FL): StatPearls Publishing; 2018 JanAvailable from http://www.ncbi.nlm.nih.gov/books/ NBK531459/

7. Shao X, Chen D, Xu P, Peng M, Guan C, Xie P, Yuan C, Chen B. Primary Philadelphia chromosome positive acute myeloid leukemia: A case report. Medicine (Baltimore). 2018 Nov;97(44):e12949. doi: 10.1097/MD. 0000000000012949 .

8. Kuan JW, Su AT, Leong CF, Osato M, Sashida G. Systematic review of pre-clinical chronic myeloid leukaemia. Int J Hematol. 2018 Nov;108(5):465-484. doi: 10.1007/s12185-018-2528-x.

9. Marchetti M. Cost-effectiveness of kinase inhibitors for hematologic malignancies: a systematic and critical review. Expert Rev Pharmacoecon Outcomes Res. 2017 Oct;17(5):469-480. doi: 10.1080/14737167.2017.13668 58 .
10. Rajpal S, Nampoothiri RV, Sreedharanunni S, Parihar M, Malhotra P, Varma N. Granulocytic dysplasia: an indicator of clonal evolution in patients with chronic myeloid leukemia. Blood Res. 2018 Jun;53(2):180-181. doi: 10.5045/br.2018.53.2.180.

11. Bhatia R. Novel approaches to therapy in CML. Hematology Am Soc Hematol Educ Program. 2017 Dec 8;2017(1):115-120. doi: 10.1182/asheducation-2017.1.1 15 .

12. Kota VK, Kong JH, Arellano M, El Rassi F, Gaddh M, Heffner LT, Winton EF, Jillella AP, McLemore ML, Khoury HJ. Outcomes of Newly Diagnosed Chronic Phase Chronic Myeloid Leukemia Following an Elective Switch From Second-Generation Tyrosine Kinase Inhibitor to Imatinib. Clin Lymphoma Myeloma Leuk. 2017 Dec;17(12):e71-e73. doi: 10.1016/j.clml.2017.09.004.

13. Kwak JY, Kim SH, Oh SJ, Zang DY, Kim H, Kim JA, Do YR, Kim HJ, Park JS, Choi CW, Lee WS, Mun YC, Kong JH, Chung JS, Shin HJ, Kim DY, Park J, Jung CW, Bunworasate U, Comia NS, Jootar S, Reksodiputro AH, Caguioa PB, Lee SE, Kim DW. Phase III Clinical Trial (RERISE study) Results of Efficacy and Safety of Radotinib Compared with Imatinib in Newly Diagnosed Chronic Phase Chronic Myeloid Leukemia. Clin Cancer Res. 2017 Dec 1;23(23):7180-7188. doi:m10.1158/1078 -0432.CCR-17-0957.

14. Tojo A, Kyo T, Yamamoto K, Nakamae H, Takahashi N, Kobayashi Y, Tauchi T, Okamoto S, Miyamura K, Hatake K, Iwasaki H, Matsumura I, Usui N, Naoe T, Tugnait M, Narasimhan NI, Lustgarten S, Farin H, Haluska F, Ohyashiki K. Ponatinib in Japanese patients with Philadelphia chromosome-positive leukemia, a phase 1/2 study. Int J Hematol. 2017 Sep;106(3):385-397. doi: 10.1007/s12185-017-2238-9.

15. Fischer JT, Ho AD, Wilhelm M, Goebeler ME, et al. German CML Study Group. Long-term outcome of patients with newly diagnosed chronic myeloid leukemia: a randomized comparison of stem cell transplantation with drug treatment. Leukemia. 2016 Mar;30(3):562-9. doi: 10.1038/leu.2015.281.

16. Jiang Q, Zhao D, Jin J, Wu D, Meng F, Hu J, Liu B, DU X, Liu T, Li Y, Hou M, Han X, Shen Z, Ma J. [A prospective, multi-centre clinical trial to evaluate the early clinical efficacy and safety of a generic imatinib in treating patients with chronic phase of chronic myelogenous leukemia]. Zhonghua Xue Ye Xue Za Zhi. 2015 Aug;36(8):651-5. doi: 10.3760/cma.j.issn.0253-2727.20 15.08.005.

17. Hochhaus A, Rosti G, Cross NC, Steegmann JL, et al. Frontline nilotinib in patients with chronic myeloid leukemia in chronic phase: results from the European ENEST1st study. Leukemia. 2016 Jan;30(1):57-64. doi: 10.1038/leu.2015.270. 